Pacelhe et al.

\title{
$1 \quad$ Nectar quality affects ant aggressiveness and biotic defense provided to plants
}

3 FÁBIO T. PACELHE* ${ }^{1}$, FERNANDA V. COSTA ${ }^{2}$, FREDERICO S. NEVES $^{1,3}$, JUDITH BRONSTEIN $^{4} \&$

$4 \quad$ MARCO A. R. MELLO 5

$5{ }^{1}$ Graduate School in Ecology, Conservation and Wildlife Management, Federal University of Minas Gerais, Belo 6 Horizonte, Brazil.

$7 \quad{ }^{2}$ Department of Biodiversity Evolution and Environment, Federal University of Ouro Preto, Ouro Preto, Brazil.

$8{ }^{3}$ Department of General Biology, Federal University of Minas Gerais, Belo Horizonte, Brazil.

$9{ }^{4}$ Department of Ecology and Evolutionary Biology, University of Arizona, Tucson, AZ, USA.

$0 \quad{ }^{5}$ Department of Ecology, University of São Paulo, São Paulo, Brazil.

\section{Abstract}

4 An excellent model to investigate how biological attributes of species affect interaction outcomes are plants 5 bearing extrafloral nectaries and the ants that feed at them. As plant-provided resources are essential components 6 of ant diets, plants that offer more nutritious food to ants should be better defended in return, as a result of more .7 aggressive behavior towards natural enemies. We tested this hypothesis in a field experiment by adding artificial 8 nectaries to individual plants of the species Vochysia elliptica (Vochysiaceae). Ants were offered one of four 9 liquid foods of different nutritional quality: amino acids, sugar, sugar + amino acids, and water (control). We 0 used live termites (Nasutitermes coxipoensis) as model herbivores and observed ant behavior towards them. In 88 $1 \mathrm{~h}$ of observations, we recorded 1,009 interactions with artificial nectaries involving 1,923 individual ants of 26

Received; Revision accepted.

${ }^{1}$ Corresponding author; e-mail: fabiotulio.bio@gmail.com 
2 species. We recorded 381 encounters between ants and termites, of which 38 percent led to attack. In addition, 61

3 percent of these attacks led to termite exclusion from the plants. Recruitment and patrolling were highest when

4 ants fed upon nectaries providing sugar + amino acids, the most balanced and nutritious food. This increase in

5 recruitment and patrolling led to higher encounter rates between ants and termites, more frequent attacks, and

6 faster and larger termite removal. Our results are consistent with the hypothesis that plant biotic defense is

7 mediated by resource quality. We highlight the importance of qualitative differences in nectar composition for the 8 outcome of ant-plant interactions.

9 Keywords: ant-plant interactions; behavioral ecology; Brazil; chemical ecology; extrafloral nectar; mutualism;

0 Serra do Cipó.

\section{Resumo}

i Um excelente modelo para investigar como os atributos biológicos das espécies afetam o resultado das interações

4 são plantas com nectários extraflorais e as formigas que se alimentam delas. Como os recursos fornecidos pelas

5 plantas são componentes essenciais na dieta de formigas, as plantas que oferecem alimento mais nutritivo às

6 formigas devem ser melhor defendidas em retorno, como resultado de um comportamento mais agressivo em

7 relação aos inimigos naturais. Nós testamos esta hipótese em um experimento de campo adicionando nectários

8 artificiais em plantas individuais da espécie Vochysia elliptica (Vochysiaceae). As formigas receberam um dos

9 quatro alimentos líquidos de diferentes qualidades nutricionais: aminoácidos, açúcar, açúcar + aminoácidos e

.0 água (controle). Utilizamos cupins vivos (Nasutitermes coxipoensis) como modelo de herbívoro e observamos os

.1 comportamentos das formigas em relação a eles. Em 88 h de observações, registramos 1.009 interações com

.2 nectários artificiais envolvendo 1.923 indivíduos de 26 espécies de formigas. Registramos 381 encontros entre

3 formigas e cupins, dos quais 38\% levaram ao ataque. Além disso, $61 \%$ desses ataques levaram à exclusão dos

.4 cupins das plantas. Recrutamento e patrulhamento foram maiores quando as formigas se alimentaram de nectários

.5 com açúcar + aminoácidos, o alimento mais equilibrado e nutritivo. Esse aumento no recrutamento e 
6 patrulhamento leva a uma maior taxa de encontro entre formigas e cupins, ataques mais frequentes e uma maior e

7 mais rápida remoção de cupins. Nossos resultados são consistentes com a hipótese de que a defesa biótica das

8 plantas é mediada pela qualidade dos recursos. Além disso, destacamos a importância das diferenças qualitativas

9 na composição do néctar para o resultado das interações entre formigas e plantas.

1 HOW THE BIOLOGICAL ATTRIBUTES OF DIFFERENT SPECIES AFFECT THE OUTCOMES OF THEIR .2 INTERACTIONS IS ONE OF THE MAIN OPEN QUESTIONS IN ECOLOGY (Sutherland et al. 2013). This

3 question has no simple answer, as thousands of species with different features interact with one another and 4 establish relationships that vary from positive to neutral to negative (Chamberlain et al. 2014). It is necessary to 5 disentangle this complexity to understand the processes that drive interaction outcomes and their consequences 6 for ecological functions and evolutionary dynamics. see Marazzi et al. 2013) are a good model in which to study context-dependence of interaction outcomes (Bronstein 1998, Del-Claro et al. 2016). These interactions are generally assumed to be mutually beneficial, since plants provide food for ants, which in turn deter herbivores and other natural enemies (Rosumek et al. 2009). This

Interactions between ants and plants with extrafloral nectaries (secretory glands not related to pollination; defensive biotic response can be explained by increased ant visitation and "ownership" behavior on plants that provide a predictable and valuable food source (Ness et al. 2009, Fagundes et al. 2017). The defense provided by ants can have strong effects on plant fitness, as suppression of herbivory conserves resources that might then be allocated to vegetative growth and reproduction (Nascimento \& Del-Claro 2010, Rosumek et al. 2009). Although the chemical composition of extrafloral nectar has been studied in detail (Heil 2015), little is known about how nectar components might drive the aggressive behavior of ants that visit plants (González-Teuber \& Heil 2009a).

The effects of ants on plants are commonly context-dependent, ranging from positive (Sendoya et al. 2016) to negative (Chamberlain \& Holland 2009), as a function of biotic (Koch et al. 2016) and abiotic (Jones et al. 2017) conditions. For the outcome to be positive for the plants, the cost of producing nutritious extrafloral nectar 
'0 must not exceed the benefits of the biotic defense provided in return (Bronstein 2001). Production of extrafloral

'1 nectar has been presumed to be inexpensive (O’Dowd 1979), which makes it likely that even occasional ant

'2 defense might be worth the investment. However, the assumption that a high-quality reward may drive ant

'3 behavior, improving plant defense, has rarely been tested (but see Flores-Flores et al. 2018). The physiological

'4 costs of nectar production may vary not only genetically (Rutter \& Rausher 2004), but also plastically, in

'5 response to local availability of nutrients and water (Reich et al. 2003). Furthermore, from the ants' perspective,

'6 low-quality nectar might not be worth finding, collecting, and defending, if alternative resources are available

7 (Stadler \& Dixon 2008).

'8 In nature, the chemistry of nectar is extremely complex, with a wide variety of sugars and amino acids

'9 differing in concentration across species (Blüthgen et al. 2004, Heil 2011). To understand the potential influence

:0 of the nutritional quality of extrafloral nectar on the outcome of ant-plant interactions, we must first consider the

:1 importance of different nutrients. Ants require a balanced diet of sugars and amino acids, and ant species that

:2 normally collect carbohydrate-rich nectar may exhibit a strong preference for protein- or amino acid-rich

i3 resources (Kay 2002). Evidence suggests that consumption of extrafloral nectar alters the optimal balance of

i4 carbohydrates and proteins in ant diets, leading ants to require additional protein intake (Ness et al. 2009). This

i5 protein deficit is usually resolved by consuming other plant visitors (including herbivores), which in turn boosts

:6 biotic defense (Ness et al. 2009). Consistent with these observations, cafeteria trials indicate that ants generally

:7 prefer artificial mixtures containing both sugar and amino acids over those with sugar only (Blüthgen \& Fiedler

is 2004b). In addition, evidence suggests that nectar composition plays a central role in determining ant competitive

:9 hierarchies, with the most dominant species monopolizing better plant rewards (Blüthgen \& Fiedler 2004a). Thus,

0 offering high quality nectar, which we assume here is a more nutritionally balanced reward, can confer benefits to

11 the host plant. In addition, different lines of evidence have led to the hypothesis that plants that offer higher-

12 volume and more sugar-rich extrafloral nectars receive better biotic defense in return, mostly due to the

3 dominance of competitively superior ants (Fagundes et al. 2017, Flores-Flores et al. 2018). 
A common feature in the study of mutualism is a consideration of the 'effectiveness' of mutualistic partners 15 in conferring benefits, measured by both quantitative and qualitative parameters (González-Teuber et al. 2012, Dáttilo et al. 2015, Lange et al. 2017, Fagundes et al. 2017, Flores-Flores et al. 2018). However, the meaning of effectiveness, quantity, and quality vary greatly across studies. The conceptual framework proposed by Schupp et al. (2017) contributes to clarifying these concepts. They offer a general effectiveness framework for viewing the processes and outcomes of mutualistic interactions, based on a consistent terminology and a restricted range of metrics, which apply to both sides in any type of mutualism. This framework encompasses two central components that might predict mutualist efficiency: (1) the quantity component of effectiveness, which measures the number of immediate outcomes of the interaction; and (2) the quality component of effectiveness, which incorporates post-interaction delayed outcomes. A way to apply this concept to ant-plant protection mutualisms would be measure the number of enemies removed, whether by killing or repelling, as a function of the number of visitors attending the plant and the probability that an attending visitor removes an enemy, interpreted as the quantity component, and evaluate the proportional increase in fruit production per enemy removed, being a function of the amount of resources saved per enemy removed and the proportional increase in fruit production per unit resource, representing the quality component (for more details, see figure 2c in Schupp et al. 2017).

Here, we report on an experiment in which we manipulated the two most important chemical components of extrafloral nectars: sugar and amino acids. Specifically, we tested whether the nutritional value of nectar, mutualism (Schupp et al. 2017). We carried out a field experiment using treatments with artificial extrafloral 
Pacelhe et al.

8 resource quality influences the effectiveness of a plant protection mutualism, offering insights into how nectar 9 composition affects consumer behavior and biotic defense.

0

1 METHODS

2

3 STUDY AREA. - The study was carried out at Serra do Cipó National Park (hereafter Serra do Cipó), located in 4 the southern region of Espinhaço Range, state of Minas Gerais, Brazil (19²0'55.93" S, 43³7'10.23" W). The 5 region is markedly seasonal, with rainy summers and dry winters, and an average annual rainfall of $1450 \mathrm{~mm}$ 6 (Alvares et al. 2013). Our experiment was carried out along a 3-km-long trail, locally known as Capão dos $7 \quad$ Palmitos (19²0'57.78" S, 43³7'00.46" W and 19²1'59.08" S, 43³7'12.78" W, 832-937 m a.s.1.). Capão dos

8 Palmitos represents an ecotone between Cerrado (savannas) and Campos Rupestres (rupestrian grasslands) 9 occupied by species of both environments, such as plants of the families Vochysiaceae, Asteraceae, and $0 \quad$ Velloziaceae (Mota et al. 2017).

2 EXPERIMENTAL DESIGN. - We used as a model the plant Vochysia elliptica Mart. (Vochysiaceae), one of the 3 most abundant small trees in Serra do Cipó (Shimizu \& Yamamoto 2012). This species lacks extrafloral nectaries 4 and other secretory structures unrelated to pollination (Stafleu 1948). We specifically chose a plant lacking 5 extrafloral nectaries so as to isolate the effects of the variable we were attempting to test (the chemical content of 6 extrafloral nectar). The use of artificial nectaries allowed us to control temporal (Baker-Méio \& Marquis 2012, 7 Falcão et al. 2014, Dáttilo et al. 2015) and ontogenetic (Heil et al. 2000) variations in qualitative and quantitative 8 nectar properties. Furthermore, our method excluded natural variation in production and quality of natural nectar 9 influenced by ant consumption (Heil et al. 2000) and by the production of volatile organic compounds (VOCs) 0 produced by plants that are being consumed (Heil \& Bueno 2007). Further, we used only plants at non1 reproductive phases, since inflorescences might attract ants (Romero 2002) and create a confounding factor. 
We selected 40 individual plants up to $2 \mathrm{~m}$ in height spaced at least $5 \mathrm{~m}$ apart. As the absence of EFN is not a constraint to ant presence on plants since different ant species commonly forage on plant surface looking for different resource types (Costa et al. 2016), before installing artificial nectaries, we did 30 observations of 3-min (a diurnal and other nocturnal) on 15 individual plants for three d (13-15 January 2015) to sample the set of ant species that naturally forage in surface of $V$. elliptica. As we expected, very few ants were observed to be foraging on plant. We found only six ant occurrences represented by a single individual each: Brachmyrmex sp1 and Crematogaster prox. erecta once, and Camponotus crassus and Ectatomma tuberculatum twice.

After these initial observations, we arbitrarily placed five artificial nectaries on each plant, one on the main branch (trunk) and the other four on the medial part of different secondary branches (between the trunk and the apex). The artificial nectaries were $2 \mathrm{ml}$ Eppendorf vials with a cotton thread extending from each. The vials were filled with the solution defined for each treatment. Artificial EFNs were used as suggested by Blüthgen \& Fiedler (2004b), but we modified their distribution. Instead of placing pairs of Eppendorf vials at a single location or distributing ten pairs along the tree trunk with different concentrations (which was not possible due to the small size of $V$. elliptica), we chose to distribute the Eppendorf vials throughout the plant and to offer different concentrations on different individuals. This way, we could distribute the resources evenly on the plants, to attract ants homogeneously, allowing us to observe their behavior while controlling for resource quality. We established four treatments with ten plants assigned to each: amino acids (hereafter A) -3 percent of amino acid solution ( $1 \%$ glutamine, 1\% proline, and 1\% threonine); sugar (hereafter S) - 30 percent of sucrose solution; sugar + amino acids (hereafter $\mathrm{S}+\mathrm{A}$ ) -20 percent sucrose +3 percent of amino acid solution (using the same amino acids as in the A treatment); and filtered water (hereafter W) as a control. Treatments were arbitrarily assigned to plants sequentially from north to south of the trail.

Few studies have assessed the chemical profile of natural EFN. Among those, there is information on the chemistry of nectar at the species (Shenoy et al. 2012), clade (González-Teuber \& Heil 2009b), and community levels (Blüthgen et al. 2004). The composition and concentration of sugars and amino acids vary extensively 
across species. As we found no studies at the community level that traced the chemical profile of EFN in the

7 Cerrado, we had to consider the scant information available to define the experimental concentrations. By

8 analyzing the data presented by Blüthgen et al. (2004), we found that, among 16 plants sampled in the rainforest

9 at North Queensland, Australia, the concentration of total sugars ranged from 7 percent (Macaranga tanarius;

0 Euphorbiaceae) to 76 percent (Entada phaseoloides; Fabaceae), with an average value of $21 \pm 8 \%$. In addition, the

1 total concentration of amino acids ranged from 0.02 percent (Homalanthus novoguinnensis; Euphorbiaceae) to

22.67 percent (Smilax australis; Smilacaceae) with an average value of $0.3 \pm 0.07 \%$. Our nectar concentrations were

'3 defined taking into account the mean concentration of nectars produced by all plants sampled by Blüthgen et al.

4 (2004), excluding those belonging to families that do not occur in the Brazilian Cerrado. Our objective here was

5 not to mimic the complex composition of natural nectars, but to see how ants responded to qualitative variation in

6 nectar composition, considering the two most prominent components of nectar in nature: sugar and amino acids.

$7 \quad$ We used sucrose because most ant species prefer it to glucose or fructose (Blüthgen \& Fiedler 2004b), and

8 glutamine, proline and threonine because they are the amino acids found most frequently and in the highest

9 concentration in extrafloral nectar of several plant species (Blüthgen et al. 2004). In nature, when nectar

0 composition is more complex (i.e., when there is a wider variety in chemical components), there is a balance in

1 chemical concentration: high-sugar nectars have a lower variety of amino acids, and nectars with a higher variety

2 of amino acids are lower in sugar (Blüthgen et al. 2004). Therefore, we used a lower sugar concentration in $\mathrm{S}+\mathrm{A}$

3 treatment compared to the $\mathrm{S}$ treatment. In addition, a pilot experiment carried out in the study site revealed that 20

4 percent and 30 percent sucrose solutions did not differ in attractiveness to ants (richness: GLMM - deviance

$5 \quad(1,19)=27.7, \mathrm{R}^{2}=0.3, \chi^{2}=0.55, \mathrm{P}=0.45 ;$ abundance: $\operatorname{GLMM}-$ deviance $(1,19)=67.5, \mathrm{R}^{2}=0.03, \chi^{2}=0.55, \mathrm{P}=$ $6 \quad 0.45)$.

8 ANT BEHAVIOR TOWARDS MODEL HERBIVORES. - After installing the artificial nectaries, we filled and 9 monitored them daily for 12 d (20 - 31 January 2015), until their contents were consumed or evaporated. During 
0 this period, we recorded ant richness and abundance, as well as occurrence and frequency of interactions. After

1 this period, we noticed a stabilization in the frequencies of ant visitation and their abundances and "ownership"

2 behavior near the food source. We only began the behavioral experiment with termites after this preliminary test.

3 As stated above, the artificial nectar offered in our experiment was a simplification of natural EFN, and was

4 composed of the main nutrients observed in natural EFN. Nevertheless, there is evidence that our experimental

5 conditions induced natural behaviors. Even using a relatively simple food, we obtained similar results as other

6 studies that measured the behavior of ants while interacting with natural EFNs or hemipteran honeydew

7 (Katayama \& Suzuki 2005, Campos \& Camacho 2014).

To evaluate the biotic defense provided by ants, on each $V$. elliptica plant we placed one live Nasutitermes

9 coxipoensis, the most common termite species in the study area (Nunes et al. 2017). Termites are commonly used

I0 to simulate herbivores in studies of ant-plant interactions (e.g., Oliveira et al. 1987; Campos and Camacho 2014),

1 as they can be added in controlled numbers and ants readily attack them; here, the goal was simply to evaluate the

12 behavior of different ant species towards a standardized threat. The termite was released on the apex of the

3 secondary branch most distant from the trunk, so it could move freely around the plant. We observed the host

14 plant it for $30 \mathrm{~min}$, recording every 5 min the number of ants (defined as recruitment), the number of ants that

15 interacted with the termite, and the ants' behavior towards the termite.

16 We considered an ant-termite interaction to be an attack when the ant injured or consumed the termite, and

17 a touch when the ant touched the termite with its antennae without injuring it. The outcome was considered

8 neutral when the ant did not interact with the termite (following Katayama and Suzuki 2005). We also recorded

9 the number of attacks after first contact and whether these attacks led to termite exclusion from the plant.

We stopped observing the ants after 30 min or when the termite was consumed, left the plant, or fell from

1 the plant due to vibrations caused by wind or ant attacks. The observations were made for $26 \mathrm{~d}$ (2-27 February

2 2015). We carried out a total of eight observations on each plant, four diurnal (from 0600 to $1200 \mathrm{~h}$ ) and four

3 nocturnal (from 1800 to $2400 \mathrm{~h}$ ), totaling 320 observation events and $88 \mathrm{~h}$ of observations in field. For nocturnal 
4 observations, we used a headlamp with a red plastic filter to avoid disturbing the ants. We sampled the spectrum 5 of ants over $24 \mathrm{~h}$, because the composition of ant species interacting with extrafloral nectary-bearing plants is 6 known to differ between day and night (Dáttilo et al. 2014, Anjos et al. 2016).

7

8

To measure biotic defense, we calculated the following metrics during each observation event: encounter rate, minimum time to encounter, attack rate, exclusion success, and efficiency of exclusion (see Table 1 and Katayama and Suzuki 2005 for detailed information about defense metrics). We then compared these metrics across the four nectar-quality treatments.

STATISTICAL ANALYSIS. - We used generalized linear mixed models (GLMM, Crawley 2013) to test the first two predictions, that ants should (1) exhibit higher recruitment and patrolling and (2) attack termites more frequently and remove them in larger number on plants whose extrafloral nectar has been enriched with sugar plus amino acids,. We calculated those models using the lmer function of the package lme4 (Bates et al. 2014) for R (R Development Team 2015). In these models, we assumed temporal pseudoreplication, and considered metrics related to biotic defense as dependent variables and the treatment as the fixed factor. Plant identity was used as random factor in our models since each individual plant was observed eight times.

To test prediction 3, that ants should remove termites faster on plants whose extrafloral nectar was enriched with sugar and amino acids, we used a survival analysis with Weibull distribution (Weibull 1951), inside package survival (Therneau 2015) for R. For this analysis, we used termite exclusion from host plant (binary variable: $1=$ exclusion and $0=$ no exclusion) and the time spent for exclusion as response variables, and treatment as explanatory factor.

For all GLMM models, when significant differences were observed among treatments, the models were submitted to contrast analysis by aggregating different levels of treatment variable and testing whether the model with the new arrangement is different from the previous one (Crawley 2013). Thus, if the level of aggregation did 
7 not alter the deviance explained by the previous model $(p>0.05)$, the levels were pooled and the model was 8 adjusted.

\section{- RESULTS}

.2 We recorded 1,009 interactions with artificial nectaries, involving 1,923 individual ants from 26 species and six 3 subfamilies, on the experimental plants. The richest ant subfamilies, Myrmicinae and Formicinae, were 4 represented by nine species each. Camponotus was the most frequent genus, with five species (Table S1).

The treatment with sugar (S) attracted the largest number of ant species (19, 73\% of all ant species observations, representing only 23 percent of the interactions observed with the artificial nectars (Table S1), without displaying defensive behavior. Eight ant species (31\%) attacked and either excluded or consumed the termites: Brachmyrmex sp1, Camponotus blandus, C. crassus, C. rufipes, C. renggeri, C. vittatus, Ectatomma tuberculatum, and Pseudomyrmex gracillis. The species Brachmyrmex sp1, C. vittatus and P. gracillis displayed attack and exclusion behaviors only two times each in nine, ten and five observations, respectively. The other five ant species frequently displayed attack and exclusion behaviors. They were responsible for 96 percent of attack observations and 93 percent of exclusion occurrences, being numerically and behaviorally dominant (as defined by Cerdá et al. 2013) in all treatments, only varying among treatments in their recruitment rates (Table S2). We recorded 381 encounter events between ants and termites. Out of those encounters, 38 percent led to attack behavior and 61 percent of these attacks led to termite exclusion from plants.

Ants recruited to the sugar $(\mathrm{S})$ and sugar + amino acids $(\mathrm{S}+\mathrm{A})$ treatments twice as often as to the amino acid (A) treatment, and ten times more than to the water $(\mathrm{W})$ treatment $\left(\right.$ Deviance $_{(5,315)}=1967.3, R^{2}=0.22, \chi^{2}=$

9 31.32, $P<0.001$; Fig. 1). Supporting prediction 1 , the $\mathrm{S}+\mathrm{A}$ treatment showed the highest encounter rate: the 
1 treatments $\left(\right.$ Deviance $_{(4,316)}=163.3, R^{2}=0.05, \chi^{2}=9.55, P=0.001$; Fig. 1). Supporting prediction 2, ants attacked

2 termites more frequently on plants assigned the $\mathrm{S}+\mathrm{A}$ treatment. Attack rate was twice as high in the $\mathrm{S}+\mathrm{A}$

3 treatment than in either the $\mathrm{S}$ or A treatment and 7.6 times higher than in the $\mathrm{W}$ treatment (Deviance $(5,315)=165$,

$4 R^{2}=0.19, \chi^{2}=11.25, P=0.003$; Fig. 1). Termite removal from the plant was also higher in the $\mathrm{S}+\mathrm{A}$ treatment,

5 with an exclusion success rate 2.5 times higher than in the $\mathrm{S}$ or $\mathrm{A}$ treatment and 16 times higher than in the $\mathrm{W}$

6 treatment $\left(\right.$ Deviance $_{(5,315)}=254.9, R^{2}=0.17, \chi^{2}=30.93, P<0.001$; Fig. 1).

7 Supporting prediction 3, ants found the termites twice as fast in the S+A treatment than in either the S or A

8 treatment and 2.6 times faster than in the $\mathrm{W}$ treatment (Deviance $(5,315)=2462.7, R^{2}=0.22, \chi^{2}=26.3, P<0.001$ ).

9 In addition, ants removed termites from the plants twice as fast in $\mathrm{S}+\mathrm{A}$ than in either the $\mathrm{S}$ or the $\mathrm{A}$ treatments.

0 We found no difference in the time taken by ants to exclude live termites in the S and A treatments, but both

1 differed from the control (W treatment; Deviance $_{(2,316)}=54.85 ; P<0,001 ;$ Fig. 2). Thus, in the $\mathrm{S}+\mathrm{A}$ treatment, 2 ants removed 50 percent of the termites in half the time $(14 \mathrm{~min})$ it took in the other treatments $(\mathrm{S}=27 \mathrm{~min} ; \mathrm{A}=$ $3 \quad 31 \mathrm{~min}$ and $\mathrm{W}=67 \mathrm{~min})$.

\section{DISCUSSION}

7 Our results are consistent with the hypothesis that biotic defense depends on the quality of the reward offered by

8 plants. Specifically, our results suggest that plants that offer more nutritious extrafloral nectar receive better biotic

9 defense in return, due to increased aggressiveness. Consumption of high-quality nectar composed of sugar +

0 amino acids was associated with higher ant recruitment, higher ant aggressiveness, and higher exclusion

1 efficiency of a surrogate herbivore compared to nectar containing only sugar or amino acids.

Five ant species were dominant in all treatments and are considered as "core" in the studied environment

3 (see Ribeiro et al. 2018). These ants have traits that define dominance, such as massive recruitment and high 4 aggressiveness, suggesting that they can be considered "mutualists of high quantitative value", one of the 
5 components of the plant protection effectiveness framework (Schupp et al. 2017). We observed a marked 6 dominance hierarchy in the $\mathrm{S}$ and $\mathrm{S}+\mathrm{A}$ treatments, with the five numerically and behaviorally dominant species 7 using the resources, foraging, attacking termites and defending the plants. The other ant species arrived in smaller numbers and fed from nectaries occupied by dominant species, but never showed defensive behaviors. In sum, 9 our observations show that in this system, attracting more high-quality mutualists is more important than 0 attracting more species. These results are in agreement with Miller (2007), who showed that EFN-bearing plants 1 visited by multiple ant species received reduced benefits relative to those associated with a single, high quality 2 mutualist species (see also Mody \& Linsenmair 2004, Del-Claro \& Marquis 2015).

In nature, the chemistry of nectar is highly complex, with a wide variety of sugars and amino acids occurring in different concentrations in different plant species (Heil 2011). Our study shows that even a quite 5 simple food, containing either only sugar or only amino acids, can attract ants and promote biotic defense. Although the nectar composition used in our experiment was a simplified version of the composition observed in 7 nature, we obtained similar results as other studies that have studied ants interacting with EFNs and hemipteran 8 honeydew (Katayama \& Suzuki 2005, Campos \& Camacho 2014), suggesting that we were observing natural 9 behaviors.

Although in nature, extrafloral nectar is never composed of amino acids alone, our results call attention to the importance of this nutrient in eliciting mutualistic ant behaviors. Nectars composed by a single nutrient (S or A) produced similar levels of defense (same capacity to encounter, attack, and exclude termites), while the treatment with both nutrients led to improved biotic defense. This suggests that the effects of those two nutrients might be synergistic (as proposed by Raubenheimer \& Simpson 1997). In fact, S+A effects are higher than the 2011). Moreover, at the colony level, energy requirements differ among individuals. While worker ants require mainly carbohydrates for their activities, larval development requires consumption of proteins and amino acids 
9 (Sorensen et al. 1981). Consequently, nectars that contain a broader spectrum of nutrients are thought to be more 0 balanced and valuable for the ant colony (Heil 2011).

1 Even though carbohydrates are an important driver of ant foraging (Rudolph \& Palmer 2013) and 2 aggressiveness (Grover et al. 2007), evidence from our study and from the literature (see Blüthgen \& Fiedler 3 2004a, Heil 2011) shows that amino acids are critical. The mechanisms responsible for triggering different ant 4 behaviors remain unclear, as information on the role of amino acids in ant metabolism is scarce. We know that 5 sugars and amino acids contribute independently to nectar attractiveness (González-Teuber \& Heil 2009a), but 6 amino acids can act as a flavor enhancer, stimulating different chemoreceptors in insects and influencing their 7 perception of nectar taste (Gardener \& Gillman 2002). Considering that ants need to maximize their intake of 8 carbon and nitrogen (Ness et al. 2009), a more aggressive behavior upon consumption of amino-acid-enriched 9 nectar may be a result of interspecific competition (Davidson 1998) driven by the low availability of these 0 resources in nature. Alternatively, an increase in energy availability in nectar may lead directly to higher ant 1 aggressiveness (Kay et al. 2010). In conclusion, we have presented new evidence that a nectar that combines carbohydrates and amino acids 3 leads to an increase in ant aggressiveness compared to nectar with only one of those nutrients. Consequently, 4 amino acid-enriched nectar boosts ant efficiency in removing herbivores, which potentially improves the quality 5 of the biotic defense received by the plants. A successful mutualism should maximize the cost-benefit 6 relationship for both ants and plants. Our study suggests that, from the plant's perspective, including amino acids 7 in extrafloral nectaries might increase the chance of a positive outcome in their interactions with ants. This 8 relationship should be especially strong in nitrogen-limited environments, such as Cerrado and Campo Rupestre, 9 where carbon is abundant but nitrogen is scarce (Oliveira et al. 2016). As our results suggest that a more balanced 0 and nutritious nectar with amino acids, although being more expensive to the plants, improves ant defense 1 behavior, plants should secrete a valuable nectar in situations in which they might benefit from better protection 2 (Smith et al. 1990). As extrafloral nectar secretion follows optimal defense theory (Holland et al. 2009) and 
3 highly aggressive ants may tilt the balance to a negative outcome for plants (Melati \& Leal 2018), natural

4 selection should favor secretion of enriched nectar in situations in which the benefits provided by ants surpass the 5 costs, as periods when herbivore pressure is higher (Millán-Cañongo et al. 2014).

\section{ACKNOWLEDGEMENTS}

8 We are grateful to many colleagues who helped us in different stages of this project. We thank Igor Mateus 9 Alves for helping us in the field and lab, and Marina Beirão and Arleu Viana for helping in the statistical analysis. 0 Paulo Peixoto made invaluable suggestions to an early version of this manuscript. We thank the Chico Mendes 1 Institute of Biodiversity Conservation (ICMBio) for the research permit and the logistic support. FT Pacelhe 2 received a Master's scholarship from the Brazilian Coordination for the Improvement of Higher Education 3 Personnel (CAPES). FV Costa received a sandwich PhD scholarship from the German Academic Exchange 4 Service (DAAD). MAR Mello was funded by the Dean of Research of the Federal University of Minas Gerais 5 (UFMG/PRPq, 01/2013, 14/2013, and 02/2014), Brazilian Council for Scientific and Technological Development 6 (CNPq, 472372/2013-0 and 302700/2016-1), Minas Gerais Research Foundation (FAPEMIG, APQ-01043-13 7 and PPM-00324-15), and Alexander von Humboldt Foundation (AvH, 3.4-8151/15037). The Graduate School in 8 Ecology, Conservation and Wildlife Management of UFMG (PPG-ECMVS) provided us with research 9 infrastructure.

1 DATA AVAILABILITY

2 The data used in this study are archived at the Dryad Digital Repository:

4 SUPPORTING INFORMATION

5 Additional Supporting Information may be found online in the supporting information tab for this article: 
Pacelhe et al.

6 TABLE S1. List of ant species found visiting the experimental plants (Vochysia elliptica) subjected to different

7 nectar quality treatments.

8 TABLE S2. Parameters used to calculate the protection effectiveness of eight ant species that attacked and either 9 excluded or consumed the termites.

-0 FIGURE S1. Synergistic effects of $S+A$ treatment compared to treatments $S$ and $A$.

\section{LITERATURE CITED}

3 Alvares, C. A., J. L. Stape, P. C. Sentelhas, J. L. M. Gonçalves, and G. Sparovek. 2013. Köppen's climate classification map for Brazil. Meteorol. Zeitschrift 22: 711-728.

5 Anjos, D. V., B. Caserio, F. T. Rezende, S. P. Ribeiro, K. Del-Claro, and R. Fagundes. 2016. Extrafloralnectaries and interspecific aggressiveness regulate day/night turnover of ant species foraging for nectar on Bionia coriacea. Austral Ecol. 42: 317-328.

BAKER-MÉIO, B., and R. J. MARQUIS. 2012. Context-dependent benefits from ant-plant mutualism in three sympatric varieties of Chamaecrista desvauxii. J. Ecol. 100: 242-252.

Bates, D., M. Mächler, B. Bolker, and S. WALKER. 2014. Fitting Linear Mixed-Effects Models using lme4.

1 BlÜthGen, N., and K. FiEdLER. 2004a. Competition for composition: Lessons from nectar-feeding ant 2 communities. Ecology 85: 1479-1485.

3 BlÜthgen, N., and K. Fiedler. 2004b. Preferences for sugars and amino acids and their conditionality in a 4 diverse nectar-feeding ant community. J. Anim. Ecol. 73: 155-166.

5 BlÜthgen, N., G. GotTSBerger, and K. FiedLer. 2004. Sugar and amino acid composition of ant-attended nectar and honeydew sources from an Australian rainforest. Austral Ecol. 29: 418-429.

Bronstein, J. L. 2001. The costs of mutualism. Am. Zool. 41: 825-839. 
o BYK, J., and K. DeL-CLARO. 2011. Ant-plant interaction in the Neotropical savanna: direct beneficial effects of 1 extrafloral nectar on ant colony fitness. Popul. Ecol. 53: 327-332.

2 CAMPOS, R. I., and G. P. CAMACHO. 2014. Ant-plant interactions: the importance of extrafloral nectaries versus hemipteran honeydew on plant defense against herbivores. Arthropod. Plant. Interact. 8: 507-512.

CERDÁ, X., X. ARnAn, and J. RETANA. 2013. Is competition a significant hallmark of ant (Hymenoptera: Formicidae) ecology? Myrmecological News 18: 131-147.

Chamberlain, S. A., J. L. Bronstein, and J. A. Rudgers. 2014. How context dependent are species interactions? Ecol. Lett. 17: 881-890.

Chamberlain, S. S., and J. N. Holland. 2009. Quantitative synthesis of context dependency in ant-plant protection mutualisms. Ecology 90: 2384-92.

Costa, F. V., M. A. R. Mello, J. L. Bronsteinl, T. J. Guerra, R. L. Muylaert, A. C. Leite, and F. S. Neves. 2016. Few ant species play a central role linking different plant resources in a network in rupestrian grasslands. PLoS One 11: 1-17.

Crawley, M. J. 2013. The R book. Wiley, Chichester, West Sussex, United Kingdom.

Dáttilo, W., A. Aguirre, R. V. Flores-Flores, R. Fagundes, D. Lange, J. García-Chávez, K. Del-Claro, and V. RICO-GRAY. 2015. Secretory activity of extrafloral nectaries shaping multitrophic ant-plant-herbivore interactions in an arid environment. J. Arid Environ. 114: 104-109.

Dáttilo, W., R. Fagundes, C. A. Q. Gurka, M. S. A. Silva, M. C. L. Vieira, T. J. Izzo, C. Díaz-Castelazo, K. Del-Claro, and V. Rico-Gray. 2014. Individual-based ant-plant networks: Diurnal-nocturnal structure and species-area relationship. PLoS One 9: 1-9.

DAVIDSON, D. W. 1998. Resource discovery versus resource domination in ants: a functional mechanism for breaking the trade-off. Ecol. Entomol. 23: 484-490. an Ant Protection System in Brazilian Cerrado. Biotropica 47: 459-467. 
Del-Claro, K., V. Rico-Gray, H. M. Torezan-Silingardi, E. Alves-Silva, R. Fagundes, D. Lange, W.

DÁttilo, A. A. Vilela, A. Aguirre, and D. Rodriguez-Morales. 2016. Loss and gains in ant-plant interactions mediated by extrafloral nectar: fidelity, cheats, and lies. Insectes Soc. 63: 207-221.

Fagundes, R., W. DÁttilo, S. P. Ribeiro, V. Rico-Gray, P. Jordano, and K. Del-Claro. 2017. Differences among ant species in plant protection are related to production of extrafloral nectar and degree of leaf herbivory. Biol. J. Linn. Soc. 88: 442-447.

FALCÃo, J. C. F., W. DÁtTILO, and T. J. IzzO. 2014. Temporal variation in extrafloral nectar secretion in different ontogenic stages of the fruits of Alibertia verrucosa S. Moore (Rubiaceae) in a Neotropical savanna. J. Plant Interact. 9: 1-6.

Flores-Flores, R. V., A. Aguirre, D. V. Anjos, F. S. Neves, R. I. Campos, and W. DÁttilo. 2018. Food source quality and ant dominance hierarchy influence the outcomes of ant-plant interactions in an arid environment. Acta Oecologica 87: 13-19.

GARDENER, M. C., and M. P. GiLlman. 2002. The taste of nectar - a neglected area of pollination ecology. Oikos 98: $552-557$.

GonzÁlez-Teuber, M., and M. HeIL. 2009a. Nectar chemistry is tailored for both attraction of mutualists and protection from exploiters. Plant Signal. Behav. 4: 809-813.

GonZÁlez-Teuber, M., and M. HeIl. 2009b. The role of extrafloral nectar amino acids for the preferences of facultative and obligate ant mutualists. J. Chem. Ecol. 35: 459-468.

GonzÁlez-Teuber, M., J. C. Silva Bueno, M. Heil, and W. Boland. 2012. Increased Host Investment in Extrafloral Nectar (EFN) Improves the Efficiency of a Mutualistic Defensive Service. PLoS One 7: 1-9.

Grover, C. D., A. D. Kay, J. A. Monson, T. C. Marsh, and D. A. Holway. 2007. Linking nutrition and behavioural dominance: carbohydrate scarcity limits aggression and activity in Argentine ants. Proc. R. Soc. B 274: 2951-2957.

HeIL, M. 2011. Nectar: generation, regulation and ecological functions. Trends Plant Sci. 16: 191-200. 
8 HeIL, M. 2015. Extrafloral nectar at the plant-insect interface: a spotlight on chemical ecology, phenotypic $9 \quad$ plasticity and food webs. Annu. Rev. Entomol. 60: 213-232.

0 HeIL, M., and J. C. S. BUENO. 2007. Within-plant signaling by volatiles leads to induction and priming of an 1 indirect plant defense in nature. Proc. Natl. Acad. Sci. 104: 5467-5472.

2 Heil, M., B. Fiala, B. Baumann, and K. E. Linsenmair. 2000. Temporal, spatial and biotic variations in extrafloral nectar secretion by Macaranga tanarius. Funct. Ecol. 14: 749-757.

Holland, J. N., S. A. Chamberlain, and K. C. Horn. 2009. Optimal defence theory predicts investment in extrafloral nectar resources in an ant-plant mutualism. J. Ecol. 97: 89-96.

Jones, I. M., S. Koptur, H. R. Gallegos, J. P. Tardanico, P. A. Trainer, and J. Peña. 2017. Changing light conditions in pine rockland habitats affect the intensity and outcome of ant-plant interactions. Biotropica 49: 83-91.

Katayama, N., and N. SuZUKI. 2005. The importance of the encounter rate between ants and herbivores and of ant aggressiveness against herbivores in herbivore exclusion by ants on Vicia angustifolia L. (Leguminosae) with extrafloral nectaries. Appl. Entomol. Zool. 40: 69-76.

KAY, A. 2002. Applying optimal foraging theory to assess nutrient availability ratios for ants. Ecology 83: 19351944.

Kay, A. D., T. Zumbusch, J. L. Heinen, T. C. Marsh, and D. A. Holway. 2010. Nutrition and interference competition have interactive effects on the behavior and performance of Argentine ants. Ecology 91: 57-64.

Koch, E. B. A., F. Camarota, and H. L. Vasconcelos. 2016. Plant Ontogeny as a Conditionality Factor in the Protective Effect of Ants on a Neotropical Tree. Biotropica 48: 198-205.

Lange, D., E. S. CaliXto, and K. Del-Claro. 2017. Variation in Extrafloral Nectary Productivity Influences the Ant Foraging R. M. Borges (Ed.). PLoS One 12: 1-13.

Marazzi, B., J. L. Bronstein, and S. Koptur. 2013. The diversity, ecology and evolution of extrafloral nectaries: Current perspectives and future challenges. Ann. Bot. 111: 1243-1250. 
Pacelhe et al.

2 Melati, B. G., and L. C. LeAl. 2018. Aggressive bodyguards are not always the best: Preferential interaction 3 with more aggressive ant species reduces reproductive success of plant bearing extrafloral nectaries. PLoS $4 \quad$ One 13: 1-13.

5 Millán-Cañongo, C., D. Orona-Tamayo, and M. Heil. 2014. Phloem Sugar Flux and Jasmonic Acid6 Responsive Cell Wall Invertase Control Extrafloral Nectar Secretion in Ricinus communis. J. Chem. Ecol. $7 \quad 40: 760-769$.

Miller, T. E. X. 2007. Does having multiple partners weaken the benefits of facultative mutualism? A test with cacti and cactus-tending ants. Oikos 116: 500-512.

Mody, K., and K. E. LinSENMAIR. 2004. Plant-attracted ants affect arthropod community structure but not necessarily herbivory. Ecol. Entomol. 29: 217-225.

Mota, G. silva, G. R. Luz, N. M. Mota, E. S. Coutinho, M. D. M. Veloso, G. W. Fernandes, and Y. R. F. NUNES. 2017. Changes in species composition, vegetation structure, and life forms along an altitudinal gradient of rupestrian grasslands in south-eastern Brazil. Flora 1: 1-41.

Nascimento, E. A., and K. Del-Claro. 2010. Ant visitation to extrafloral nectaries decreases herbivory and increases fruit set in Chamaecrista debilis (Fabaceae) in a Neotropical savanna. Flora Morphol. Distrib. Funct. Ecol. Plants 205: 754-756.

Ness, J. H., W. F. Morris, and J. L. Bronstein. 2009. For ant-protected plants, the best defense is a hungry offense. Ecology 90: 2823-2831.

Nunes, C. A., A. V. Quintino, R. Constantino, D. Negreiros, R. Reis Júnior, and G. W. Fernandes. 2017. Patterns of taxonomic and functional diversity of termites along a tropical elevational gradient. Biotropica 49: 186-194.

O’DowD, D. 1979. Foliar nectar production and ant activity on a neotropical tree, Ochroma pyramidale. Oecologia 43: 233-248.

Oliveira, P., A. Silva, and A. MARTINS. 1987. Ant foraging on extrafloral nectaries of Qualea granditlora 
Pacelhe et al.

(Vochysiaceae) in cerrado vegetation: ants as potential antiherbivore agents. Oecologia 74: 228-230.

Oliveira, R. S., A. Abrahão, C. Pereira, G. S. Teodoro, M. Brum, S. Alcantara, and H. Lambers. 2016. Ecophysiology of Campos Rupestres Plants. In G. W. Fernandes (Ed.) Ecology and Conservation of Mountaintop Grasslands in Brazil. pp. 227-272, Springer International Publishing, Switzerland.

R DeVElopment TEAm. 2015. R: A language and environment for statistical computing. R Foundation for Statistical Computing.

RAUBENHEIMER, D., and S. J. SIMPSON. 1997. Integrative models of nutrient balancing: application to insects and vertebrates. Nutr. Reserach Rev. 10: 151-179.

Reich, P. B., I. J. Wright, J. Cavender-Bares, J. M. Craine, J. Oleksyn, M. Westoby, and M. B. Walters. 2003. The evolution of plant functional variation: traits, spectra, and strategies. Int. J. Plant Sci 164: 143164.

Ribeiro, L. F., R. R. C. Solar, D. C. Muscardi, J. H. Schoereder, and A. N. Andersen. 2018. Extrafloral nectar as a driver of arboreal ant communities at the site-scale in Brazilian savanna. Austral Ecol. 1-9.

Romero, G. Q. 2002. Protection of Vochysia elliptica (Vochysiaceae) by a nectar-thieving ant. Braz. J. Biol. 62: $371-373$.

Rosumek, F. B., F. A. O. Silveira, F. S. Neves, N. P. U. Barbosa, L. Diniz, Y. Oki, F. Pezzini, G. W. FERNANDES, and T. CORNELISSEN. 2009. Ants on plants: a meta-analysis of the role of ants as plant biotic defenses. Oecologia 160: 537-549.

RudolPh, K. P., and T. M. PALMER. 2013. Carbohydrate as fuel for foraging, resource defense and colony growth - a long-term experiment with the plant-ant crematogaster nigriceps. Biotropica 45: 620-627.

RutTER, M. T., and M. D. RAUSHER. 2004. Natural selection on extrafloral nectar production in chamaecrista fasciculata: the costs and benefits of a mutualism trait. Evolution 58: 2657-2668.

Schupp, E. W., P. JordAnO, and J. M. GóMEZ. 2017. A general framework for effectiveness concepts in mutualisms. Ecol. Lett. 20: 577-590. 
io Sendoya, S. F., N. Blüthgen, J. Y. Tamashiro, F. Fernandez, and P. S. Oliveira. 2016. Foliage-dwelling ants 1 in a neotropical savanna: effects of plant and insect exudates on ant communities. Arthropod. Plant. Interact. 12 10: 183-195.

i Shenoy, M., V. RadhikA, S. SATish, and R. M. Borges. 2012. Composition of Extrafloral Nectar Influences 14 Interactions between the Myrmecophyte Humboldtia brunonis and its Ant Associates. J. Chem. Ecol. 38: $15 \quad 88-99$.

16 ShimizU, G. H., and K. Yамамото. 2012. Flora da serra do cipó, minas gerais: Vochysiaceae. Bol. Botânica da 17 Univ. São Paulo 30: 63-87.

8 Smith, L. L. ., J. LAnZA, and G. C. . Smith. 1990. Amino Acid Concentrations in Extrafloral Nectar of Impatiens 9 Sultani Increase after Simulated Herbivory. Ecol. Soc. Am. 71: 107-115.

o Sorensen, A. A., J. T. Mirenda, and S. B. Vinson. 1981. Food exchage and distribution by three functional $1 \quad$ worker groups of the imported fire ant Solenopsis invicta buren. Insectes Soc. 28: 383-394.

2 Stadler, B., and T. Dixon. 2008. Mutualism: ants and their inset Partners. Cambridge University Press, 3 Cambridge, United kingdom.

4 Stafleu, F. A. 1948. A monography of the Vochysiaceae. I. Salvertia and Vochysia. Rec. Trav. Bot. Néerl 41: $5 \quad 379-450$.

6 Sutherland, W. J. ET AL. 2013. Identification of 100 fundamental ecological questions. J. Ecol. 101: 58-67.

7 ThERnEAU, T. 2015. A package for survival analysis in R. http://CRAN.R-project.org/package=survival. 8 Weibull, W. 1951. A Statistical Distribution Function of Wide Applicability. J. Appl. Mech. 293-234. 


\section{TABLES}

TABLE 1. Biotic defense metrics and their interpretation.

$\begin{array}{lll}\text { Defense metric Calculation } & \text { Interpretation }\end{array}$

$\begin{array}{lll}\text { Encounter rate } & \text { Total number of encounters between } & \text { A proxy for ant recruitment and } \\ \text { ants and termites divided by } & \text { patrolling on plants, which represents } \\ \text { observation time. } & \text { the probability of encounter between } \\ & \text { ants and termites. }\end{array}$

Minimum time Time spent for the first encounter

for encounter between one ant and the termite.

Attack rate

Total number of ant attacks to termites

divided by the total number of

encounter during observation.
A proxy for patrolling efficiency of ants on plants.
Exclusion success Events of termite exclusion (binary

rate variable, being 1 when there is

exclusion and 0 when there is no
A proxy for ant aggressiveness, and an estimate of the probability of an attack event when the ant encounters the termite.

\section{exclusion) divided by the total number plant.}

of ant attacks to termites.

Exclusion

efficiency
Events of termite exclusion (binary

variable, being 1 when there is

exclusion and 0 when there is no
A proxy for ant aggressiveness, which shows how many ant attacks are needed to exclude the termite from the

A proxy for the time spent by the ant to exclude the termite from the plant. 
exclusion) divided by observation

time. 


\section{FIGURE LEGENDS}

FIGURE 1. Relationship between nectar quality (treatment) and ant defense behavior, estimated in a field experiment with artificial extrafloral nectaries, using live termites as model herbivores. Treatments: $\mathrm{A}=$ amino acids, $\mathrm{S}=$ sugar, $\mathrm{S}+\mathrm{A}=$ sugar + amino acids, $\mathrm{W}=$ water $($ control). $(\mathrm{A})$ The $\mathrm{S}$ and $\mathrm{S}+\mathrm{A}$ treatments showed higher ant recruitment than the other treatments. (B) Ants showed higher probability of finding termites in the $\mathrm{S}+\mathrm{A}$ treatment. (C) Ants showed higher probability of attacking termites in the $\mathrm{S}+\mathrm{A}$ treatment and (D) a smaller number of attacks were needed to exclude termites in the $\mathrm{S}+\mathrm{A}$ treatment. Bars represent median values with quartiles. Letters indicate statistical differences between treatments.

FIGURE 2. Time spent by ants to exclude live termites from plants subjected to different treatments of nectar quality. Treatments: $\mathrm{A}=$ amino acids, $\mathrm{S}=$ sugar, $\mathrm{S}+\mathrm{A}=$ sugar + amino acids, $\mathrm{W}=$ water (control). The proportion of excluded termites in each treatment was measured for $30 \mathrm{~min}$. Termite exclusion was fastest in the $\mathrm{S}+\mathrm{A}$ treatment, in which 14 min were needed to exclude $50 \%$ of the termites from the plants (dashed horizontal line). In the $\mathrm{A}$ and $\mathrm{S}$ treatments, which lead to similar results, it took the ants 27 and $31 \mathrm{~min}$, respectively, to exclude $50 \%$ of the termites from the plants. 


\section{FIGURES}

FIGURE 1.
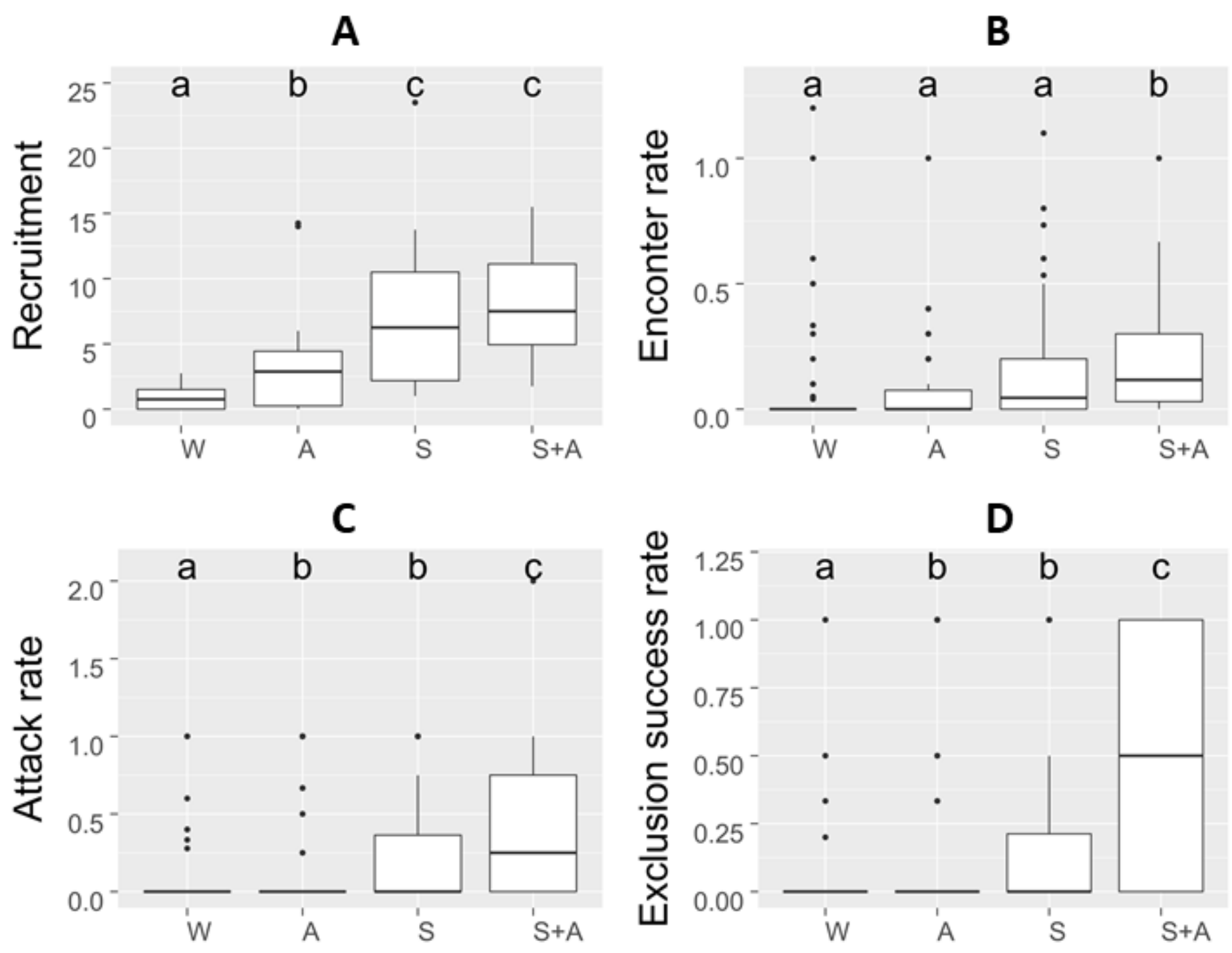

Treatment 


\section{FIGURE 2.}

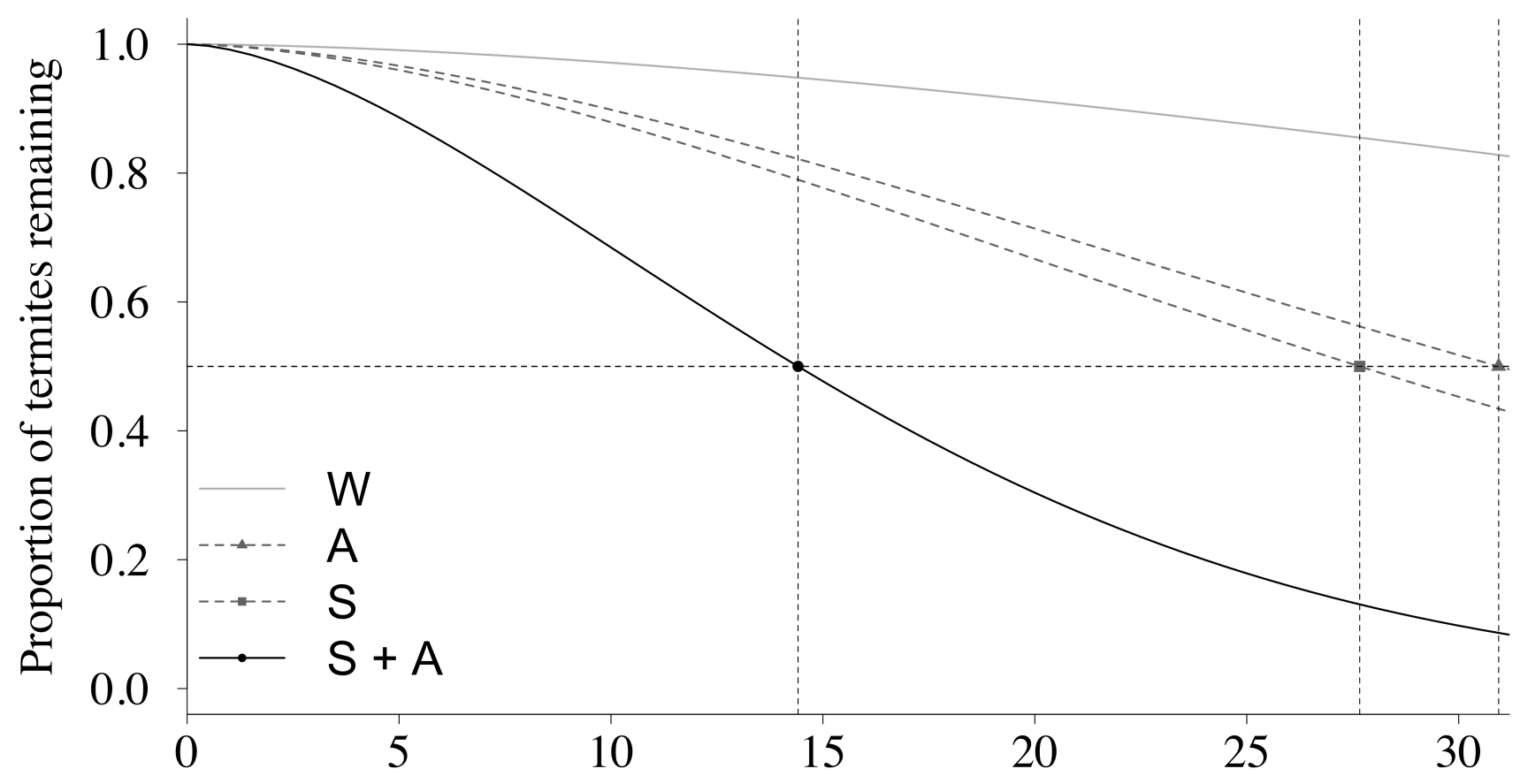

Time spent to exclude the termites (min) 


\section{SUPPORTING INFORMATION}

Table S1. List of ant species found visiting the experimental plants (Vochysia elliptica) subjected to different nectar quality treatments. The first four columns represent the number of plants visited by ants species according to the nectar quality. T-Occur. means the total number of observations by ant species in relation to the total observations; T-Abun. means total recruitment of workers ants in all observations; Abun-Int. means the total number of interactions between workers ants and artificial nectaries.

\section{Occurrence of ants}

Ants species

\begin{tabular}{llll|l|l|l}
\hline \multicolumn{3}{c}{ Treatments } & & \\
\cline { 1 - 3 } W T-Occur. & T-Abun. & Abun-Int. \\
\cline { 1 - 2 } & A & S & S + A & & & \\
\hline
\end{tabular}

\section{Subfamily Dolichoderinae}

\begin{tabular}{|c|c|c|c|c|c|c|c|}
\hline Dorymirmex sp1 & - & - & $1 / 10$ & - & $2 / 320$ & 5 & 1 \\
\hline Forelius maranhaoensis & - & - & $2 / 10$ & $1 / 10$ & $5 / 320$ & 71 & 59 \\
\hline Tapinoma sp1 & - & - & $1 / 10$ & - & $1 / 320$ & 12 & 12 \\
\hline Tapinoma sp2 & - & - & $1 / 10$ & - & $1 / 320$ & 3 & 3 \\
\hline
\end{tabular}

\section{Subfamily Ecitoninae}

Neivamyrmex sp1 $\quad-\quad \quad-\quad 1 / 10$




\section{Occurrence of ants}

Ants species

Treatments

$\begin{array}{llll}\mathbf{W} & \mathbf{A} & \mathbf{S} & \mathbf{S}+\mathbf{A}\end{array}$

T-Occur. T-Abun. Abun-Int.

Subfamily Ectatomminae

Ectatomma

tuberculatum

$5 / 10 \quad 2 / 10 \quad 4 / 10 \quad 4 / 10$

$51 / 320$

288

143

tuberculatum

micinae

Subfamily Formicinae

\begin{tabular}{|c|c|c|c|c|c|c|c|}
\hline Brachmyrmex sp1 & $1 / 10$ & $2 / 10$ & $3 / 10$ & - & $9 / 320$ & 77 & 56 \\
\hline Brachmyrmex sp2 & $1 / 10$ & $2 / 10$ & $6 / 10$ & $3 / 10$ & $13 / 320$ & 53 & 52 \\
\hline Camponotus blandus & $3 / 10$ & $2 / 10$ & $4 / 10$ & $2 / 10$ & $29 / 320$ & 243 & 115 \\
\hline Camponotus crassus & $5 / 10$ & $7 / 10$ & $7 / 10$ & $7 / 10$ & $93 / 320$ & 712 & 365 \\
\hline Camponotus renggeri & $1 / 10$ & $2 / 10$ & $2 / 10$ & $2 / 10$ & $12 / 320$ & 134 & 40 \\
\hline Camponotus rufipes & $2 / 10$ & $2 / 10$ & $2 / 10$ & $2 / 10$ & $29 / 320$ & 112 & 48 \\
\hline Camponotus vittatus & $2 / 10$ & $2 / 10$ & $2 / 10$ & $3 / 10$ & $10 / 320$ & 14 & 3 \\
\hline Myrmelachista sp1 & $1 / 10$ & - & - & - & $2 / 320$ & 65 & 4 \\
\hline
\end{tabular}




\section{Occurrence of ants}

Ants species

\section{Treatments}

T-Occur. T-Abun. Abun-Int.

$\begin{array}{llll}\mathbf{W} & \mathbf{A} & \mathbf{S} & \mathbf{S}+\mathbf{A}\end{array}$

Subfamily Formicinae

Myrmelachista sp2
Subfamily Myrmicinae

\section{Subfamily Myrmicinae}

Cephalotes eduarduli

$1 / 10 \quad 1 / 10$

$1 / 10$

$2 / 320$

4

4

Cephalotes pusillus
Crematogaster prox.

erecta

Nesomyrmex sp1

$1 / 10$

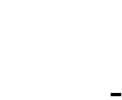

$-$

$2 / 320$

\begin{tabular}{l|l}
\hline 4 & 4 \\
\hline
\end{tabular}




\section{Occurrence of ants}

\begin{tabular}{|c|c|c|c|c|c|c|c|}
\hline \multirow[t]{2}{*}{ Ants species } & & Tr & tment: & & \multirow{2}{*}{ T-Obs } & \multirow{2}{*}{ T-Abun } & \multirow{2}{*}{ Abun-Int } \\
\hline & $\mathbf{W}$ & $\mathbf{A}$ & $\mathbf{S}$ & $\mathbf{S}+\mathbf{A}$ & & & \\
\hline \multicolumn{8}{|c|}{ Subfamily Pseudomyrmecinae } \\
\hline Pseudomyrmex gracillis & $1 / 10$ & $1 / 3$ & $1 / 10$ & - & $5 / 320$ & 5 & 4 \\
\hline Pseudomyrmex pallidus & $1 / 10$ & $1 / 10$ & - & - & $3 / 320$ & 3 & 3 \\
\hline $\begin{array}{l}\text { Pseudomyrmex } \\
\text { termitarius }\end{array}$ & $2 / 10$ & - & - & $1 / 10$ & $4 / 320$ & 5 & 4 \\
\hline Total & $10 / 10$ & $10 / 10$ & $10 / 10$ & $10 / 10$ & $320 / 320$ & 1923 & 1009 \\
\hline
\end{tabular}


Table S2. Parameters used to calculate the protection effectiveness of eight ant species that attacked and either excluded or consumed the termites.

\begin{tabular}{|c|c|c|c|c|c|c|}
\hline Species & $\begin{array}{l}\text { Recruitment } \\
\text { of workers }\end{array}$ & $\begin{array}{l}\text { Observation } \\
\text { time (min) }\end{array}$ & $\begin{array}{c}\text { Encounter } \\
\text { with } \\
\text { Termites }\end{array}$ & $\begin{array}{l}\text { Termites } \\
\text { attacked }\end{array}$ & $\begin{array}{l}\text { Termites } \\
\text { removed }\end{array}$ & $\begin{array}{l}\text { Exclusion } \\
\text { efficiency }\end{array}$ \\
\hline Brachmyrmex sp1 & 77 & $12 \pm 2.5$ & 2 & 2 & 2 & $0.08 \pm 0.02$ \\
\hline Camponotus blandus & 243 & $8.9 \pm 3.1$ & 34 & 18 & 9 & $0.13 \pm 0.05$ \\
\hline Camponotus crassus & 712 & $10.5 \pm 4.7$ & 189 & 69 & 32 & $0.12 \pm 0.06$ \\
\hline Camponotus renggeri & 134 & $8.3 \pm 2.3$ & 24 & 10 & 6 & $0.13 \pm 0.05$ \\
\hline Camponotus rufipes & 112 & $8.42 \pm 4$ & 49 & 24 & 19 & $0.14 \pm 0.06$ \\
\hline Camponotus vittatus & 14 & $12.5 \pm 7.5$ & 3 & 2 & 2 & $0.12 \pm 0.05$ \\
\hline Ectatomma tuberculatum & 288 & $5.1 \pm 4.9$ & 78 & 19 & 17 & $0.12 \pm 0.06$ \\
\hline Pseudomyrmex gracillis & 5 & $7.5 \pm 2.5$ & 2 & 2 & 2 & $0.15 \pm 0.05$ \\
\hline Total & 1585 & - & 381 & 146 & 89 & - \\
\hline
\end{tabular}


Figure S3. Synergistic effects of the S + A treatment compared to the treatments S and A summed (i.e., S A). Statistical parameters from final models indicate that the effect size of the $\mathrm{S}+\mathrm{A}$ treatment is higher than the effect sizes of the S and A treatments summed (S - A). For Encounter Rate (A), the final GLMM model shows that there is no difference in effect size between the $\mathrm{S}, \mathrm{A}$ and $\mathrm{W}$ treatments and that altogether they are even lower than the $\mathrm{S}+\mathrm{A}$ treatment. In other words, the effect of $\mathrm{S}+\mathrm{A}$ is higher than the sum of isolated effect of S, A and W. For Attack Rate (B), Exclusion Success Rate (C) and Exclusion Efficiency (D), the GLMM final model shows that the effect size of the $\mathrm{W}$ treatment is lower than those of the $\mathrm{S}$ and $\mathrm{A}$ treatments, that are also lower than the effect of the $\mathrm{S}+\mathrm{A}$ treatment. Thus, the effect of $\mathrm{S}+\mathrm{A}$ is higher than the sum of $\mathrm{S}$ and A effects in all biotic defense metrics. The results of Exclusion Efficiency (D) survival model are similar, but they should be interpreted in the opposite way, once this metric represent the time spent to exclude termites by ants, which means that less time spent is better (i.e., lower effect size). Dots and bars represent medium values and standard errors, respectively. 


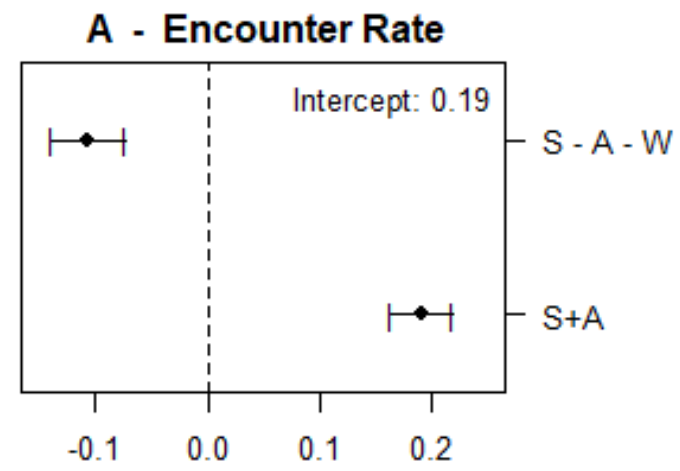

Effect Size (Estimates - GLMM)

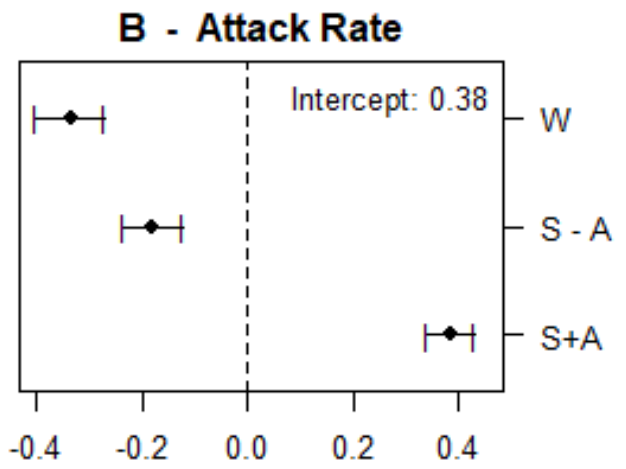

C - Exclusion Success Rate

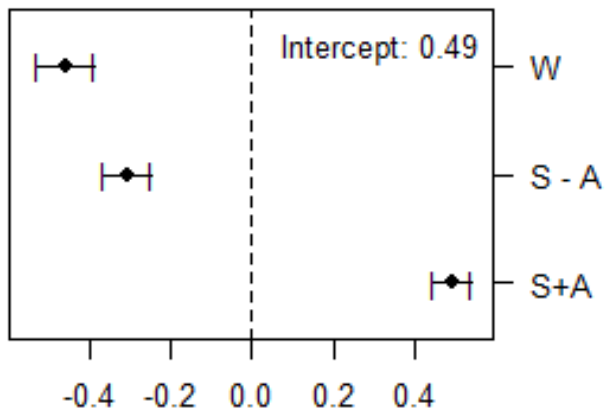

Effect Size (Estimates - GLMM)

Effect Size (Estimates - GLMM)

D - Exclusion Efficiency

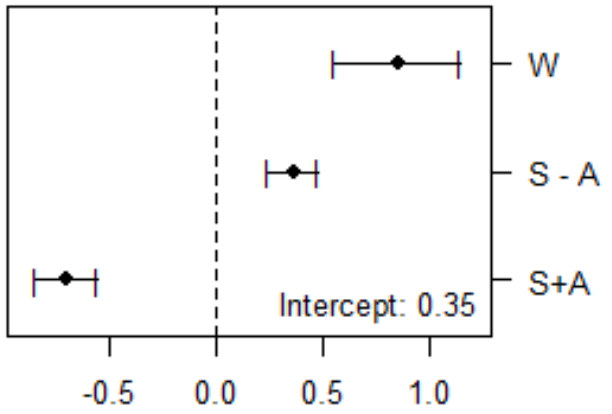

Effect Size (Value - Survival Analysis) 